\title{
A scientific note on an unusual hibernating stage in a late- flying European bee species
}

\author{
Andreas MÜLLER ${ }^{1}$, Urs WeIBEL ${ }^{2}$ \\ ${ }^{1}$ ETH Zurich, Institute of Agricultural Sciences, Biocommunication and Entomology, Schmelzbergstrasse 9/LFO, 8092, \\ Zurich, Switzerland \\ ${ }^{2}$ Museum zu Allerheiligen, Klosterstrasse 16, 8200, Schaffhausen, Switzerland
}

Received 16 May 2019 - Revised 19 September 2019 - Accepted 11 December 2019

\begin{abstract}
Most temperate wild bees overwinter in the larval or imaginal stage inside their nests after the entire larval food provisions have been consumed. Here, we report on the finding that Colletes hederae (Colletidae), a lateflying European bee species active in September and October, passes the winter as half-grown larva inside the brood cell that still contains considerable amounts of stored food. We hypothesize that the special waterproof cell lining of Colletes reduces the risk of fungal infection, liquefaction, or desiccation of the stored food and thus liberated the bees from the need to consume the entire provisions before winter, allowing for the exploitation of late-flowering plant taxa.
\end{abstract}

\section{Apiformes / Colletes hederae / Colletidae / hibernation / Stenoria analis / Food spoilage / Hedera helix}

In temperate regions of the Northern Hemisphere, most wild bees pass the winter months within the brood cells of their nests either in the prepupal, the imaginal, or-exceptionally-the pupal stage after having completely consumed the larval food provisions (Stephens et al. 1969; Westrich 2018; Forrest et al. 2019). The reason why bees do not hibernate as egg or half-grown larva in brood cells containing stored provisions might be due to the high risk that the food becomes infected by fungi or that it changes its consistency during the long winter quiescence, both of which could negatively affect egg or larval survival. In fact, the pollen-nectar provisions of bees are highly susceptible to molding, liquefaction, and desiccation. Fungal infection of the brood cells, which frequently results from the

Corresponding author: A. Müller, mueller@usys.ethz.ch

Manuscript editor : David Tarpy intrusion of moisture after the protective cell wall or cell coating has been damaged, is generally assumed to be one of the most important mortality factors of developing bee larvae (Stephens et al. 1969; Michener 2007). Furthermore, exposure to moisture may lead to the liquefaction of the provisions due to the hygroscopical properties of the pollen (Litman et al. 2011), putting the larvae in danger of drowning. Alternatively, under dry conditions, the larval provisions may desiccate and harden, rendering food uptake difficult, particularly for young larvae with weak mouthparts. This hypothesized need to reach the prepupal or imaginal stage before the onset of winter might explain why bee species that provision brood cells in late summer and fall are surprisingly scarce in temperate Europe.

Colletes hederae Schmidt \& Westrich (Colletidae) is a late-flying bee species, which nests in self-excavated burrows in sandy soil and collects pollen mainly on Ivy (Hedera helix L., Araliaceae) (Müller and Kuhlmann 2008; 
Westrich 2018). The females start provisioning their brood cells by the beginning of September and stop nesting activities by the end of October. This late reproductive period raises doubts as to whether the larvae are able to consume the entire provisions and reach the prepupal stage before winter dormancy. In fact, 28 intact brood cells excavated after an ordinary winter on 1 March 2019 at two localities in northern Switzerland near Schaffhausen ( $47^{\circ} 42^{\prime} 50^{\prime \prime} \mathrm{N} / 8^{\circ} 40^{\prime} 06^{\prime \prime}$ $\mathrm{E}$ and $47^{\circ} 41^{\prime} 09^{\prime \prime} \mathrm{N} / 8^{\circ} 48^{\prime} 38^{\prime \prime} \mathrm{E}$ ), where numerous females of $C$. hederae nested the preceding fall, invariably contained food provisions with living larvae of $C$. hederae $(n=20)$ or Stenoria analis Schaum $(n=8)$, a meloid beetle that develops as cleptoparasite in the nests of $C$. hederae (Mayet 1875; Vereecken and Mahé 2007). The larvae of $C$. hederae, which were found at depths between 25 and $45 \mathrm{~cm}$, were in the second $(n=1)$, third ( $n=14)$, and fourth $(n=5)$ instar (Fig. 1); none of them, however, was in the last instar. This finding is in line with Mayet (1875), who observed the larvae of $C$. hederae (erroneously attributed to C. succinctus) to complete food consumption not before the end of April of the following year, indicating that this bee species typically overwinters as a half-grown larva in contrast to the overwhelming majority of bees of the temperate zone.

Colletidae are unique among bees for their special lining of the brood cells (Torchio et al. 1988; Almeida 2008 and references therein). In species of Colletes, this cell lining consists of two different secretions originating from the abdominal Dufour's gland and the thoracic salivary glands, respectively, which polymerize immediately after application to form a cellophane-like membrane completely enveloping the cell contents (Fig. 1). This membrane is hermetically sealed, solid, waterproof, insoluble in both aqueous and organic solvents, and undegradable by both acidic and alkaline hydrolysis (Almeida 2008 and references therein). It thus effectively impedes water exchange between the cell interior and the environment and is expected to strongly reduce the risk of fungal infection, liquefaction, or desiccation of the stored food provisions, even during the long winter months. We therefore

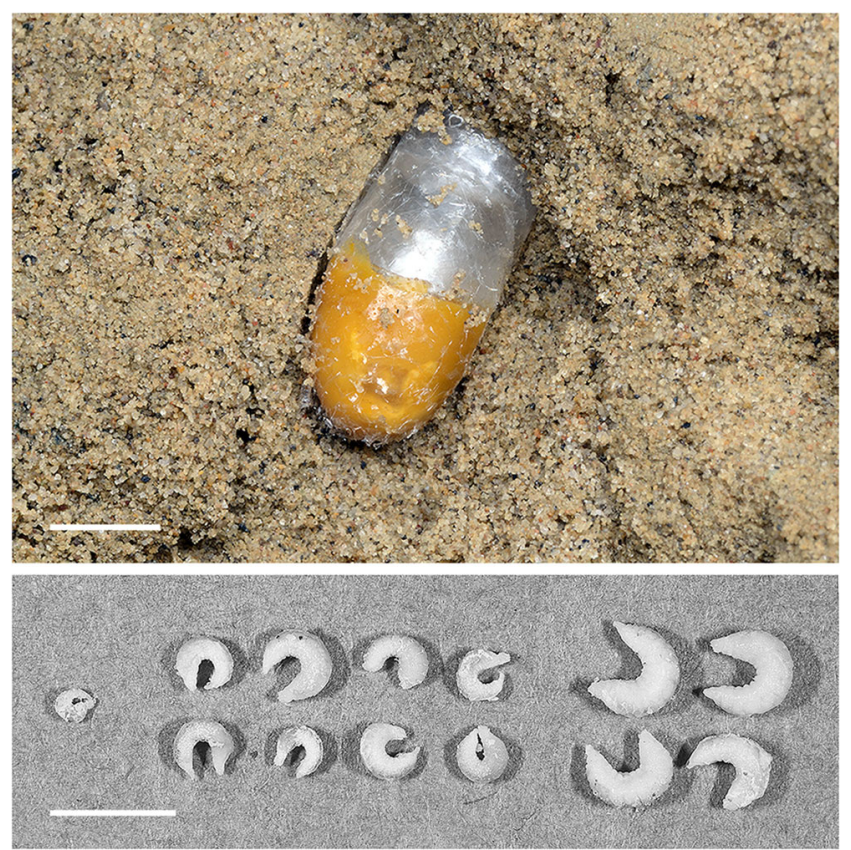

Figure 1. Brood cell of Colletes hederae in sandy soil on 1 March 2019 and overwintering larvae of $C$. hederae in the second (left), third (centre), and fourth (right) instar; white bar $=5 \mathrm{~mm}$ 
hypothesize that the special cell lining liberated Colletes hederae from the need to consume the entire provisions before the onset of winter and allowed for the exploitation of late-flowering plant taxa, such as Ivy. Interestingly, among the few Central European bees that breed late in the season, species of the genus Colletes are overrepresented, e.g., C. collaris Dours and C. halophilus Verhoeff, which exclusively collect pollen on late-flowering Asteraceae, C. succinctus (L.), which is specialized on lateblooming Ericaceae, or Colletes sierrensis FreyGessner, which is oligolectic on late-flowering species of Odontites (Orobanchaceae) (Müller and Kuhlmann 2008; Westrich 2018). All these species also enclose their cell contents inside a waterproof membrane and are thus expected to have the capability to overwinter as half-grown larvae like $C$. hederae. In summary, the cellophane-like brood cell lining of Colletes bees appears to be a preadaptation that later enabled some species to be active late in the season and to exploit plant taxa that do not start flowering until late summer and fall.

\section{ACKNOWLEDGMENTS}

We thank Petra Bachmann and Martin Bolliger (Planungs- und Naturschutzamt Schaffhausen) for the permission to dig out nests of $C$. hederae at two protected sites and two reviewers for helpful comments on the manuscript.

\section{AUTHORS CONTRIBUTIONS}

AM and UW performed the fieldwork, wrote the paper, participated in the revisions, and approved the final manuscript.

Note scientifique sur un stade d'hibernation inhabituel chez une espèce d'abeille européenne volante tardive

Apiformes / Colletes hederae / Colletidae / hibernation / Stenoria analis
Wissenschaftliche Notiz zu einem ungewöhnlichen Überwinterungsstadium bei einer spätfliegenden europäischen Bienenart

\section{Apiformes / Colletes hederae / Colletidae / Überwinterung / Stenoria analis}

\section{REFERENCES}

Almeida, E.A.B. (2008) Colletidae nesting biology, Apidologie 39, 16-29.

Forrest, J.R.K., Cross, R., CaraDonna, P.J. (2019) Two-year bee, or not two-year bee? How voltinism is affected by temperature and season length in a high-elevation solitary bee, Am. Nat. 193, 560-574.

Litman, J., Danforth, B.N., Eardley, C.D., Praz, C. (2011) Why do leafcutter bees cut leaves? New insights into the early evolution of bees, Proc. R. Soc. Lond. B 278 , 3593-3600.

Mayet, V. (1875): Mémoire sur les moeurs et les metamorphoses d'une nouvelle espèce de Coleoptère de la famille des Vésicants, le Sitaris colletis. Ann. Soc. Entomol. France 5, 65-92.

Michener, C.D. (2007) The bees of the world. The John Hopkins University Press, Baltimore.

Müller, A., Kuhlmann, M. (2008): Pollen hosts of western palaearctic bees of the genus Colletes (Colletidae) - the Asteraceae paradox. Biol. J. Linn. Soc. 95, 719-733.

Stephens, W.P., Bohart, G.E., Torchio, P.F. (1969) The biology and external morphology of bees with a synopsis of the genera of northwestern America, Corvallis, Agricultural Experiment Station, Oregon State University.

Torchio, P.F., Trostle, G.E., Burdick, D.J. (1988) The nesting biology of Colletes kincaidii Cockerell (Hymenoptera: Colletidae) and development of its immature forms. Ann. Entomol. Soc. Am. 81, 605-625.

Vereecken, N., Mahé, G. (2007) Larval aggregations of the blister beetle Stenoria analis (Schaum) (Coleoptera: Meloidae) sexually deceive patrolling males of their host, the solitary bee Colletes hederae Schmidt \& Westrich (Hymenoptera: Colletidae). Ann. Soc. Entomol. France 43, 493-496.

Westrich, P. (2018) Die Wildbienen Deutschlands, Eugen Ulmer, Stuttgart.

Publisher's note Springer Nature remains neutral with regard to jurisdictional claims in published maps and institutional affiliations. 